\title{
MITOS KESUKSESAN DALAM IKLAN BIMBINGAN BELAJAR KUMON
}

\author{
Tri Mariyanto
}

SMA Tanwir Surabaya

Email: trimariyanto@gmail.com

\begin{abstract}
Abstrak
Artikel ini mengkaji iklan KUMON dengan menggunakan metode semiologi Roland Barthes. Iklan KUMON juga dianalisa dengan menggunakan perspektif pendidikan kritis. KUMON menampilkan iklan denotatif yang memuat konotasi yang tersembunyi, melegitimasi budaya yang adalah masyarakat melalui kode, serta merepresentasikan 'kesuksesan' dengan citra serta penanda-penanda yang dipilih. Ada beberapa kecenderungan pembentukan kesadaran masyarakat dalam iklan KUMON. Pertama, kecenderungan mengajak masyarakat bersikap pragmatis dalam memandang pendidikan. Kedua, kecenderungan penyingkiran ilmu pengetahuan yang dianggap 'tidak berguna'. Iklan KUMON juga melestarikan narasi besar ekonomi pada aspek pendidikan melalui klaim universal kebutuhan untuk menjadi sukses pada masyarakat.
\end{abstract}

Kata kunci: semiologi, iklan, kumon, mitos

\section{Abstract}

This article examines the KUMON ads using the semiology of Roland Barthes. KUMON ads also analyzed using critical educational perspective. KUMON ads showing denotative that contain hidden connotations, legitimize culture is community through code, and represents the 'success' with the image and the selected markers. There are several tendencies in the establishment of public awareness in advertising KUMON. Firstly, regarding education, it invites the society to be pragmatic. Second, the tendency to remove science that are considered 'useless'. KUMON ads also preserve the larger economy narrative to education through universal claims about need to be successful in society.

Keywords: semiology, advertising, kumon, myth

\section{Latar Belakang}

Di era kapitalisme lanjut atau late capitalism ini muncul penguasa baru yang mengatur hampir seluruh sistem sosial. Bentuk baru kontrol atas kesadaran manusia baik itu mengenai cara pandang maupun tujuan-tujuan yang akan 'diakui' masyarakat sebagai sesuatu yang sah. Penguasa itu adalah media penyebar informasi yang bentuk paling sederhananya adalah iklan. Suatu konsekuensi dari kemunculan televisi yang memberi tempat pada berbagai layanan jasa informasi.

Menurut Jameson, logika budaya dan tahapan besar kapitalisme (late capitalism) tadi erat berkaitan dengan munculnya jaman post-modern, yang bercirikan adanya transformasi realitas menjadi image (Featherstone, 2008:11). Perkembangan dari era produksi komoditas barang menuju kepada konsumsi bahkan konsumsi ide. Hal inilah yang menurut Baudrillard merupakan era dimana nilai guna berubah menjadi nilai tanda (Aghinta, 2012). Kemunculan 
budaya konsumen baru yang menekankan nilai-nilai superfisial. Budaya konsumsi baru dimana simbol yang berbicara dan menjadi representasi manusia. Hal ini juga berpengaruh pada situasi sosio-kultural dan salah satunya adalah orientasi masyarakat dalam memandang kegunaan pendidikan.

Pendidikan memiliki nasib yang sama dengan konsumsi. Pendidikan akan menjadi layaknya konsumerisme yang berkawin dengan keadaan sosio-kultural yang terus berubah. Tujuan-tujuannya disesuaikan dengan keadaan global dan kehilangan ciri khasnya yang otonom. Pendidikan atau bahkan aspek lain dalam kehidupan dunia post-modern tidak dapat dilepaskan dari iklan-iklan. Pendidikan perlu promosi dan promosi harus sesuai keadaan dan kemauan khalayak, serta secara bersamaan juga membentuk kemauan khalayak dari yang tidak mau menjadi mau.

Iklan merupakan sebuah konsekensi dari penyebaran komoditi yang diproduksi kapitalis serta sistem rasional dan teknologi. Dikatakan sistem rasional karena iklan sebagai penyebar informasi yang paling mudah dan cepat serta dapat secara menyeluruh menyebar di seluruh penjuru dunia. Hal ini berkait erat dengan efektivitas dan efisiensi para kapitalis dalam menyebarkan komoditi. Tidak hanya sekedar penyebarluasan informasi tentang keberadaan suatu komoditi, iklan menurut Thomas M. Garret SJ lebih kepada alat untuk memengaruhi masyarakat untuk membeli barang atau membeli jasa, juga penyebaran ide-ide (Kasiyan dalam Suyanto, 2013:225).

Iklan juga merupakan suatu akibat dari munculnya globalisasi. Umumnya, pemaknaan sempit terhadap istilah globalisasi ialah mengenai tiadanya batas dalam penyebaran komoditi baik itu batas lokal maupun batas negara. Sehingga skala penyebaran (dalam arti penjualan) dilakukan secara internasional. Namun, bukan hanya dalam penyebaran komoditas dan produksi. Menurut Castell dan Held, globalisasi melibatkan pasar kapitalis dan sekumpulan hubungan sosial dan aliran komoditas, modal, teknologi, ide-ide, bentuk budaya, dan orangorang di seluruh perbatasan nasional melalui jaringan masyarakat global (dalam Kellner, 2002:287). Akhirnya, menurut Goran Hedebro bahwa media (termasuk juga iklan) adalah pembentuk kesadaran sosial yang pada akhirnya menentukan persepsi orang terhadap dunia dan masyarakat tempat mereka hidup (Latif \& Subandy dalam Suyoto Ed, 1994:38). Sampai muncul sindiran dari Raymond William dimana 'televisi telah merubah dunia' (2009:6).

Lalu, apa hubungan antara media iklan dengan pendidikan? Tentu tidak mungkin ada pemisahan antara satu aspek dengan yang lain. Aspek pendidikan tidak bisa dilepaskan dengan aspek lain seperti ekonomi, politik (bukan dalam arti perpolitikan kenegaraan), maupun budaya. Terdapat hubungan baik dalam bentuk tekanan maupun dorongan bagi seseorang yang 
terkait dengan tuntutan pendidikan yang tidak bisa dilepaskan dari tekanan ekonomi maupun tekanan budaya. Iklan adalah media penyebar informasi sekaligus pihak yang sangat persuasif menawarkan kemungkinan-kemungkinan keuntungan dari komoditi yang diproduksi. Terutama, keuntungan dan hasil akhir apa yang didapat dari pilihan memilih tempat belajar, baik keuntungan pengetahuan maupun keuntungan materiil. Hal ini sering menjadi orientasi umum masyarakat terkait tujuan menyekolahkan anak, misalnya seperti banyaknya orang tua memiliki persepsi bahwa sekolah adalah investasi masa depan dan sepenuhnya dipahami secara ekonomis (Nuryanto, 2010:82). Jadi, orientasi pengetahuan tergeser menjadi orientasi ekonomis. Orientasi ini direproduksi oleh iklan sekaligus membentuk produksi budaya baru yang tidak terpisah dari budaya yang nyata.

Iklan tidak mungkin menawarkan hal yang tidak menarik bagi masyarakat jika berbeda dengan keadaan sosio-kultural. Sekalipun iklan pendidikan menawarkan apa yang menjadi dasarnya, yakni; pengetahuan, selalu ada aspek lain yang ditawarkan disamping pengetahuan, seperti tawaran menjadi kaya, mapan, atau sukses dalam arti tertentu.

Iklan menawarkan gambaran-gambaran yang sebenarnya mereduksi suatu pemahaman yang luas menjadi terbatas, yakni secara visual. Misalnya saja, seseorang tidak mungkin mengerti kata 'suci' sebelum melihat secara visual apa itu 'suci'. Demikian pula dengan kesuksesan yang perlu ada gambaran yang dipersempit sehingga menjadi jelas. Penyempitan ini dilakukan dengan cara wicara dan wacana yang menurut Barthes adalah mitos. Tipe wicara yang memperkonkret yang abstrak dengan cara-cara tertentu.

Iklan sudah pasti merujuk para realitas dan pada saat yang sama juga mereproduksi realitas tersebut dengan berbagai penambahan. Sehingga pada akhirnya lebih nyata dari yang nyata. Hingga terjadi apa yang dikatakan Baudrillard bahwa yang nyata bukan berasal dari hubungan kita dengan kehidupan, melainkan dari yang ada di dalam televisi (Sarup, 2010:258). Realitas nyata tidak disajikan dengan harfiah, melainkan melalui kode-kode budaya yang berada pada tingkat konotasi suatu tanda (teks maupun visual).

Tulisan ini akan membahas bagaimana iklan pun menjadikan pendidikan sebagai komoditi ide dan menjadi pembentuk kesadaran masyarakat mengenai cara pandang terhadap pendidikan. Fokus pada tulisan ini adalah untuk membongkar tanda-tanda yang ada pada iklan KUMON terutama tentang gambaran-gambaran kesuksesan yang telah terreduksi oleh tipe wicara dan pewacanaan yang dibentuknya. Tulisan ini juga bukan merupakan tulisan tentang metode pendidikan atau segala bahasan murni tentang perkembangan pendidikan, melainkan membahas iklan yang bertema pendidikan. Sekalipun demikian, wacana mengenai pendidikan seperti orientasi masyarakat yang direproduksi iklan dan wacana pendidikan di dalam iklan 
merupakan bahasan utama. Metode pembongkaran akan dilakukan menggunakan semiologi dan mitologi Roland Barthes. Selanjutnya akan dianalisis menggunakan teori yang berkaitan dengan pendidikan kritis.

\section{Mitos Kuno dan Mitologi (Mitos Modern/Kontemporer)}

Oleh karena penelitian ini membahas mengenai mitos, penulis akan menjelaskan sedikit mengenai mitos dan mitologi. Hal ini dikarenakan untuk menghindari pemahaman yang salah mengenai dua istilah tersebut, karena biasanya mitos (terutama bagi masyarakat Indonesia) identik dengan yang berbau mistis atau legenda.

Baik masa lampau maupun masa yang akan datang tidak dapat lepas dari jeratan mitosmitos. Bedanya hanya dalam hal bentuk, sedangkan substansinya selalu sama. Mitos kuno pada awalnya merupakan suatu teori asli untuk mengenal dunia, berfungsi sebagai penceritaan asalusul dan pengenalan nilai-nilai moral pada manusia (Danesi, 2012:167). Mitos kuno ini memiliki definisi umum, berbau mistis, dan legenda.

Menurut Levi Strauss, mitos tradisional menggunakan sistem biner seperti perbedaan konsep antara yang baik dan buruk (Danesi, 2010:171). Mitos tradisional disampaikan dengan cara-cara yang sekarang dianggap sebagai hal yang irasional. Pemahaman seperti yang dinyatakan Strauss bersumber dari pemikiran Durkheim mengenai agama-agama dasar manusia, bahwa mitos mampu 'menerjemahkan' kebutuhan-kebutuhan dan aspek-aspek kehidupan tertentu manusia (Durkheim, 2011:19). Umumnya apa yang baik dan buruk digambarkan dengan makhluk-makhluk imajiner, seperti kebaikan digambarkan dengan malaikat, dan kejahatan digambarkan dengan makhluk mengerikan; setan atau monster.

Mitologi atau mitos modern memiliki cara yang sebaliknya dalam menyampaikan pengetahuan kepada manusia. jika mitos kuno menyampaikan pengetahuan dengan cara yang irasional, maka mitos modern atau mitologi menyampaikan pengetahuan dengan cara yang rasional (Danesi, 2010:173). Cara rasional ini mengikuti perkembangan peradaban itu sendiri yang telah menjadi sistem religi baru seperti pengagungan terhadap pengetahuan ilmiah maupun akumulasi ekonomi rasional.

Roland Barthes yang beraliran pemikir Perancis sedikit banyak terpengaruh oleh pemikiran strukturalisme Durkheim dan Levi Strauss. Barthes mencoba melampaui keduanya dengan mengkorelasikan kajian mitos dengan konteks yang ia alami. Menurut Barthes (2010:171-172), mitos kontemporer terdiri dari 4 artikulasi teoritis: (1) mitos merupakan 'representasi kolektif' ala Durkheimian yang muncul dalam media surat kabar maupun periklanan dan apapun yang dikonsumsi massa, (2) mitos menjungkir balik kualitas sosiokultural yang ideologis menjadi tampak natural dan lumrah, (3) mitos kontemporer bersifat 
diskontinyu dan tampil dalam bentuk wacana, (4) mitos menyembunyikan makna konotatif yang perlu dibongkar (dikritisi) dibalik sistem denotatif yang melumrahkan konotasi suatu tanda.

Mitos merupakan suatu cara penandaan, suatu 'tipe wicara' yang mengasumsikan bahwa segala sesuatu bisa menjadi mitos asalkan disajikan sebagai wacana. pesan dari wacana bisa saja terdiri dari berbagai bentuk tulisan dan representasi: bukan hanya dalam bentuk tertulis, tetapi juga berbentuk fotografi, sinema, reportase, olahraga, pertunjukan, publikasi, yang kesemuanya bisa berfungsi sebagai pendukung wacana mitis (Barthes, 2009:152-153). Dalam Pengantar Ilmu Komunikasi, dan dalam konteks yang baru John Fiske mengutarakan bahwa salah satu mitos kontemporer saat ini adalah mengenai kesuksesan disamping maskulinitas, feminitas, hingga ilmu pengetahuan (2012:143-144).

Pada dasarnya baik mitos maupun mitologi memiliki satu kata kunci, yakni ; sebuah pesan. Pesan untuk mengarahkan manusia pada pengetahuan tertentu. Termasuk dalam hal ini adalah Pencerahan yang meruntuhkan mitos. Menurut Adorno dan Horkheimer telah berbalik menjadi mitos (2002:22). Oleh karenanya, perputaran dunia terdiri dari mitos-mitos yang berbeda bentuk, tetapi secara substansial sama.

\section{Semiologi Roland Barthes}

Kajian tentang tanda adalah kajian Roland Barthes. Tanda menurut Barthes terdiri dari unsur yakni penanda (citraan mental yang bersifat verbal maupun visual) dan petanda (arti yang dimunculkan dari petanda). Konsep tersebut diambilnya dari pemikiran seorang linguistik; Ferdinand de Saussure. Selanjutnya, Barthes melampauinya dan memberi dua tingkatan lagi yakni denotasi yakni pesan lapis pertama yang nampak dan masih secara harfiah dan berhubungan dengan realitas (Barthes, 2010:4). Sedangkan konotasi mengacu pada petanda yang mendekati budaya dan pengetahuan (Barthes, 2012:134). Namun, menurut Voloshinov, kesadaran hanya dapat muncul dari wadah material dari penanda-penanda (Takwin, 2009:17), dalam hal ini adalah denotasi. Konotasi tersembunyi dalam denotasi. Tugas denotasi menyembunyikan ideologi dalam konotasi sehingga menjadi lumrah dan diterima umum. Petanda dan penanda pada lapisan pertama akan menghasilkan tanda denotatif atau pesan tingkat pertama. Tanda denotatif secara bersamaan merupakan penanda konotatif atau merupakan a petanda atau konsep bahwa Panzani memiliki gizi yang setara dengan sayuran yang ditampilkan. Sedangkan makna konotasi atau lapis keduanya adalah sifat ke-Italia-an dari produk Panzani yang sedang dijual di Perancis. 
Dalam Mitologi, Barthes membuat bagan tingkatan makna seperti berikut:

\begin{tabular}{|r|r|r|}
\hline 1. Penanda & 2. Petanda & \\
\hline 3. & Tanda Denotatif & II. Petanda \\
I. & Penanda konotatif & konotatif \\
\hline \multicolumn{4}{|r|}{ III. $\quad$ Tanda konotatif } \\
\hline
\end{tabular}

Penjelasan yang lain disajikan oleh Rusmana (2014) mengenai tingkatan tanda Roland Barthes. Konotasi sebagai sistem tersusun oleh penanda, petanda serta proses yang memadukannya (signifikansi). Signifier dari konotasi (yakni konotator) dibentuk oleh tandatanda (kesatuan signifier dan signified) dari sistem denotasi, secara predikan gabungan tanda denotasi dapat tergabung dalam konotator unggul (hal: 202). Sementara itu, petanda konotasi sekaligus berkarakter general, global, dan tersebar, merupakan fragmen ideologi (Budiman, 1999:63).

\section{Roland Barthes dalam Kajian Ini: Strukturalis atau Post-strukturalis?}

Berkaitan dengan pembongkaran mitos, ada sedikit perdebatan yang penulis coba untuk luruskan. Barthes memiliki posisi yang bisa menyesatkan banyak akademisi terkait posisi intelektualnya apakah ia merupakan seorang strukturalis atau post-strukturalis. Penulis tidak menekankan pada salah satu posisi, melainkan menyesuaikannya dengan kajian yang penulis lakukan.

Trifonas menjelaskan perbedaan kerja intelektual Barthes terkait strukturalisme dan post-strukturalisme. Pada fase strukturalisme, Barthes pada karya Elements of Semiology dan Mythologies merupakan karya Barthes pada periode strukturalis banyak menyukai kajian tentang iklan, fashion, fotografi, dan buku. Pada fase ini Barthes tertarik dengan ideologi tersembunyi yang ada pada benda-benda budaya dan melancarkan kritik padanya. Benda-benda budaya memiliki representasi yang khas dan menyimpan maksud konotatif dibalik tampilan denotatifnya(Trifonas, 2003:4).

Pada fase post-struktural kegiatan seperti itu mulai ditinggalkan. Pada fase ini, Barthes mulai mendahulukan kesenangan pembacaan dan membuat makna menjadi sekunder. Tanda menurut Barthes pada fase post-struktural menjadi tidak memiliki kekuatan representasional. Apa yang diharapkan pembaca hanyalah 'kilasan-kilasan' yang menerangi teks, namun tidak mengungkap apa-apa (Trifonas, 2003:13-14). 
Jika dibuat tabel, maka seperti berikut:

\begin{tabular}{|l|l|l|}
\hline \multicolumn{1}{|c|}{ Barthes } & \multicolumn{1}{|c|}{ Fase Strukturalis } & Fase Post-Strukturalis \\
\hline Kajian & $\begin{array}{l}\text { Kajian Budaya: iklan, fashion, } \\
\text { dan fotografi }\end{array}$ & $\begin{array}{l}\text { Kenikmatan Pembacaan } \\
\text { Atas Teks (berpengaruh } \\
\text { atas posisi makna) }\end{array}$ \\
\hline Posisi Makna & Primer & Sekunder \\
\hline Tanda & $\begin{array}{l}\text { Representasiona/Mencitrakan } \\
\text { Sesuatu }\end{array}$ & $\begin{array}{l}\text { Kosong/Tidak } \\
\text { Mencitrakan Sesuatu }\end{array}$ \\
\hline Sifat Analitis & Kritis/Pembongkaran & Puitis \\
\hline
\end{tabular}

Tujuan dari tulisan ini adalah kritik dan pembongkaran, dan oleh karenanya sangat tidak mungkin untuk menggunakan perspektif post-strukturalis-nya. Penyajian perbedaan fase intelektual Barthes ini perlu penulis cantum demi mengurangi kesalahpahaman baik terhadap Barthes sendiri maupun terhadap penulis.

Penelitian semiotika yang berhubungan dengan pendidikan pernah dilakukan Nanang Martono dalam bukunya Kekerasan Simbolik di Sekolah (2012). Kajiannya menggunakan teori-teori Bourdieu dan metodenya mengkombinasikan analisis isi dan sentuhan semiotika. Objek yang dikaji adalah buku BSE dan permasalahan yang dianggkat terdiri dari kekerasan simbolik, visualisasi yang bias kelas (sosial), dan sebagainya. Penulis ingin mencoba melakukan hal yang sama dengan Martono tetapi berbeda dalam hal permasalahan dan objek kajian.

Karya lain adalah jurnal yang ditulis oleh Dwi Ratna Aprilia yang berjudul Iklan dan Budaya Popular: Pembentukan Identitas ideologis Kecantikan Perempuan oleh iklan. Karya tersebut membahas tentang konstruksi ideologis atas kecantikan. Penelitiannya menggunakan pisau analisis semiotika Barthes. Hasil yang didapat adalah terdapat usaha penyeragaman konsep ideal mengenai kecantikan. Penulis ingin mencoba melampaui karya Aprilia dengan membahas konsep ideal kesuksesan dalam iklan.

Penulis menggunakan alat bedah semiotika dan selanjutnya akan menggunakan perspektif pendidikan kritis dalam menganalisa lebih lanjut kecenderungan ideologis dalam iklan KUMON.

Beberapa konsep ideal kesuksesan menurut gambaran $\mathrm{KUMON}$ 
Penulis akan menyajikan gambar-gambar dari iklan KUMON 3 tahun terakhir. Tujuannya adalah melihat ada kemiripan isi dari iklan KUMON dari tahun ke tahun.

Gambar 1

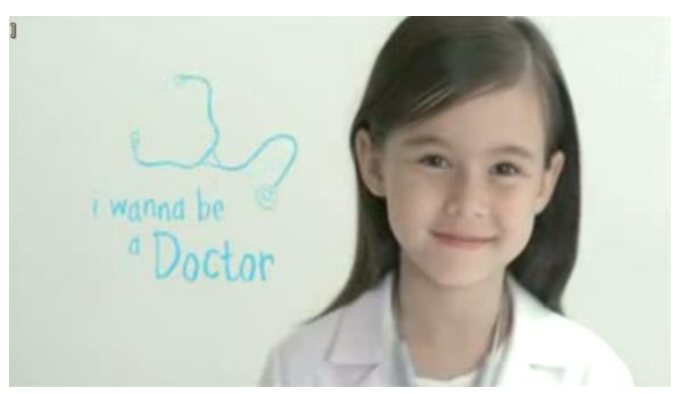

Gambar 2

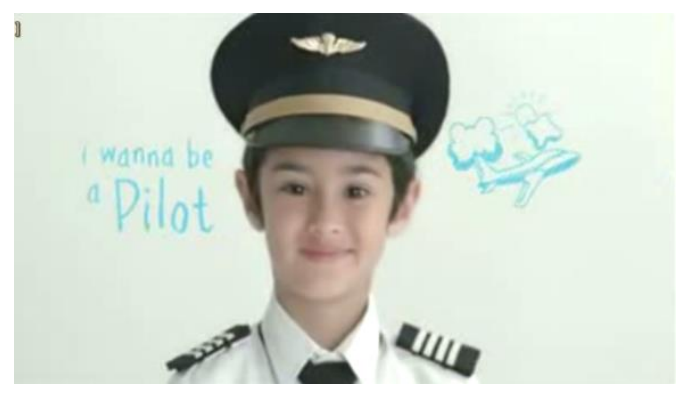

Gambar 3

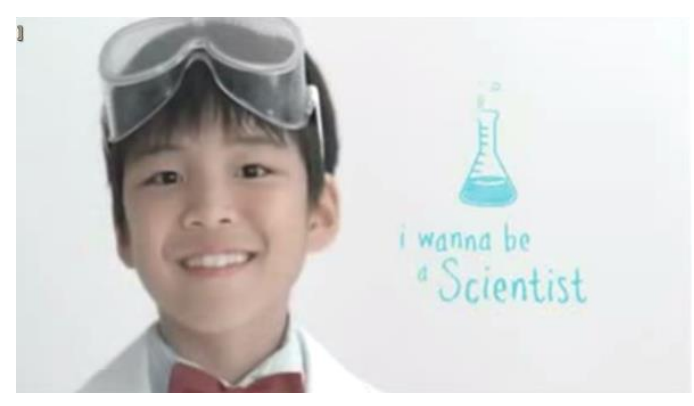

Tiga gambar diatas diambil dari iklan KUMON 2012. Gambaran kesuksesan dapat dilihat dari kombinasi tanda tingkat pertama (denotasinya) yakni ketika anak yang memakai atribut yang mencirikan cita-cita mereka, serta tulisan ungkapan cita-cita mereka. Masingmasing cita-cita itu adalah dokter, pilot, dan ilmuwan alam.

Secara konotatif, ada beberapa hal yang perlu dijelaskan. Perlu diingat kembali bahwa selain aspek ideologi, konotasi juga mencakup aspek kultural dan sosial. Hal ini dikarenakan iklan tidak mampu membuat ide baru tanpa mereproduksi dari realitas asli dan selanjutnya dilebih-lebihkan tanpa mengurangi hubungan ide iklan dengan kehidupan sehari-hari.

Gambar 1 terdiri dari penanda-penanda seperti anak perempuan dengan atribut dokter seperti jas lab dan stetoskop yang dikalungkan, dan gambar dan teks sebagi penegas bahwa anak tersebut ingin menjadi dokter. Secara denotatif, gambar 1 hanyalah penyampaian informasi bahwa KUMON dapat membuat lulusannya bisa menjadi dokter. Lalu mengapa KUMON memilih gambaran sukses dengan menggunakan dokter sebagai representasinya? Hal ini dapat ditemukan jawabannya jika melihat dan merefleksi realitas. Hal pertama yang menjadi dukungan adalah persoalan penghasilan yang diterima seorang dokter adalah cukup besar. Hal kedua, masih berkaitan dengan yang pertama, persuasi iklan yang menawarkan keuntungan material sesuai dengan tuntutan dan tekanan jaman yang serta materialistis baik dari segi 
kebutuhan maupun hubungan dan pertukaran sosial. Dengan menggunakan latar belakang sosial dan budaya, KUMON menjadikannya nilai lebih bagi lembaganya di mata masyarakat. Lagipun, buat apa iklan mempromosikan produk tanpa iming-iming yang menarik. Kasus yang sama juga terjadi pada gambar 2 yakni cita-cita menjadi pilot.

Disini, yang menjadi konotator adalah penanda-penanda seperti pakaian profesi masing-masing, teks pendukung, dan gambar pendukung. Penanda-penanda tadi membentuk kesatuan tanda-tanda di sistem denotasi yakni tentang cita-cita anak. Konotasi yang merupakan fragmen ideologi terdapat pada kode budaya. Kode budaya sendiri merupakan kode referensial dimana suara-suara kolektif yang anonim dan otoritatif mengenai pengetahuan atau kebijaksanaan atau moralitas yang "diterima bersama" (Rusmana, 2014:210). Dalam kasus pada ketiga gambar diatas, kode budayanya adalah pencapaian materialistis dan hasil (balik modal yang lebih besar) dari pendidikan; kesuksesan ideal yang digambarkan KUMON melalui iklannya. Iklan KUMON mereproduksi dan mempertahankan kode budaya.

\section{Kesuksesan dan Gender}

Gambar 1 maupun gambar 2 memiliki persoalan terkait dengan gender. Mengapa menghubungkan perempuan yang mana anak perempuan sebagai penanda representatifnya dengan dokter? Tentu, di masa sekarang sudah menjadi tren budaya yang mengakar bahwa perempuan identik dengan dokter atau pekerjaan di lingkungan medis, minimal perawat. Banyak ditemui perempuan memilih jurusan kedokteran maupun keperawatan (sekalipun lakilaki juga, tetapi tidak seperti perempuan tingkat dominasinya), atau banyak ditemui bahwa perempuanlah yang paling banyak ditemui di kampus-kampus kedokteran beserta saat kegiatan magang di rumah sakit. Penulis tidak berbicara mengenai tubuh perempuan sebagai komoditi, tetapi memang sudah menjadi tempat alamiah bahwa lingkungan medis adalah tempat kerja wanita (banyak ditemukan di film-film maupun cerita perjuangan rakyat Indonesia bahwa perempuan merawat militer yang sedang terluka bahkan sampai sekarang umum terjadi perkawinan antara laki-laki dari militer dan perempuan dari medis). Hal ini tidak perlu dibuktikan secara statistik, tetapi dari sudut pandang kultural yang sering dijumpai.

Persoalan gender lainnya adalah tentang maskulinitas era kontemporer. Jika dokter mewakili perempuan, maka pilot mewakili laki-laki. Laki-laki adalah pihak yang paling mendapat tekanan ekonomis dan masa depan yang tinggi. Hal ini disebabkan oleh wacana 'pemimpin keluarga' yang kebanyakan diartikan sebagai pemberi nafkah dan yang menentukan keadaan ekonomi keluarga. Penulis melepas dan menghindari perdebatan tentang feminisme dan ideologi gender yang lain. Sementara, hanya membahas mengenai apa yang ada di dalam iklan. Pilot diidentikkan dengan laki-laki karena memang dari segi fisik, laki-laki lebih cocok 
dalam pekerjaan tersebut. Namun, konotasi lain menyiratkan bahwa profesi pilot sendiri identik dengan kekayaan. Jika digabung dengan laki-laki, maka konotasinya adalah 'laki-laki yang wajib kaya'.

Gambaran ideal mengenai kesuksesan ini secara total mengisyaratkan bahwa kesuksesan identik dengan kaya sebagai lain biner dari miskin atau minimal 'kurang mapan'. Lagipun, iklan memiliki konteks yang sama dengan kecenderungan masyarakat kita yang pragmatis, gila gengsi, dan kekayaan dalam bentuk apapun. Gambaran yang dimunculkan iklan KUMON dapat dikata menggugah selera khalayak karena sesuai dengan budaya masyarakat. Dengan demikian, KUMON mereproduksi dan melegitimasi budaya tersebut. Hal ini dapat merusak hakikat fungsi pendidikan sebagai transformasi sosial.

Gambar 3 memang tidak menunjukkan kekhasan dari ilmuwan selain bahwa penandapenandanya menekankan dominasi ilmu alam dari ilmu lainnya. Hal ini dapat dibuktikan dengan cara paradigmatik (menghubungkan tanda dengan tanda lainnya) dengan gambar 1 dan 2 (karena masih dalam satu iklan). Gambar 1 yang menonjolkan dokter dan gambar 2 yang menonjolkan pilot memiliki hubungan dengan konotasi dari gambar 3; ilmu alam. Penanda yang tersajikan dalam gambar 3 yang mencolok adalah kacamata lab dan gambar gelas ukur. Penanda-penanda tersebut secara konotatif berhubungan dengan properti laboratorium ilmu alam. Dalam hal ini, profesi seperi dokter dan pilot memanglah berhubungan erat dengan ilmu alam. Dokter berhubungan dengan kegiatan medis dan ilmu biologi dan pilot berhubungan dengan ilmu fisika mengenai grafitasi, keseimbangan, jarak, dan kecepatan.

Selain hubungan secara keilmuan, terdapat hubungan lain seperti pengakuan secara kultural bahwa orang pintar itu pandai berhitung (ilmu eksakta). Hal ini sering dijumpai terutama pada masa anak-anak (jenjang usia yang sesuai dengan penanda dalam ketiga gambar) yang mana ilmu sosial belum dapat diterima dengan baik. Orang tua - orang tua selalu mengutamakan anaknya untuk bisa berhitung atau pandai matematik meskipun hanya dipahami secara dangkal. Dalam film-film pun selalu ilmuwan eksakta berada di garis depan representasi orang pandai.

Gambar yang telah dibahas memiliki beberapa konotasi; perolehan pekerjaan yang bernilai tinggi baik itu terkait prestige maupun penghasilan. Perolehan penghasilan tinggi ini akan dibahas dengan beberapa teori sebagai refleksi kritis di bahasan selanjutnya. Yang terakhir adalah mitos keunggulan eksakta (ideologi yang mengunggulkan eksakta). Hal ini seperti yang dijelaskan, bahwa budaya menganggap anak dianggap pintar hanya karena mahir berhitung dan mendapatkan kesuksesan materiil. Budaya ini telah mengakar dan menjadi ciri 
kolektif yang sadar maupun tidak sadar sudah diterapkan dan diimani hampir kebanyakan orang.

Budaya adalah hal yang paling menentukan terutama jika terdistorsi kebenaran aslinya oleh ideologi. Menurut Barthes, ideologi ada selama kebudayaan ada, dan konotasi merupakan suatu ekspresi budaya (Sobur, 2009:71). Jabaran pada paragraf-paragraf analisis sebelumnya adalah mengindikasikan bahwa iklan secara ideologis memanfaatkan kode budaya (salah satu dari 5 kode; hermeneutik, semantic, simbolik, dan proarietik dalam pemikiran Barthes. Kode budaya sendiri merupakan kode referensial dimana suara-suara kolektif yang anonim dan otoritatif mengenai pengetahuan atau kebijaksanaan atau moralitas yang "diterima bersama" (Rusmana, 2014:210). Dalam hal ini kondisi-kondisi pragmatis masyarakat diterima bersama pada tahap sebelumnya, dan selanjutnya iklan mereproduksi kembali dengan melakukan 'penegasan' sekaligus 'reduksi' dari suatu pemahaman seperti halnya kesuksesan.

\section{Sukses Mengenai Interest Belajar}

Iklan tidak hanya menyajika tawaran-tawaran materiil. Sebagaimana orang mengajak orang lain pada suatu hal, selalu ada usaha agar orang lain itu bisa merasa atau memiliki perasaan yang diharapkan. Untuk melakukan persuasi, iklan sebagaimana menurut Yustiman Ihza (2013) menggunakan teknik pengambilan perhatian khalayak, antra lain; teknik pengambil perhatian intrinsik. Teknik ini terdiri dari 3 macam; (1) penarik perhatian fisik, biasanya menampilkan hal yang tak lazim; (2) penarik perhatian emosi, biasanya menampilkan hal-hal yang disukai khalayak;(3) penarik perhatian kognitif dalam bentuk janji-janji yang terdapat kemungkinan menguntungkan konsumen.

Sasaran pasar iklan yang bertema pendidikan ada dua, yakni orang tua dan anak. Tetapi, anak-anak belumlah mengerti seberapa penting pendidikan untuk mereka. Anak-anak hanya mengetahui jika mereka pintar, orang tua akan mengganjar baik dan memberikan sesuatu yang menyenangkan yang mereka inginkan. Meskipun juga dapat bercita-cita dan membayangkan masa depan mereka, anak-anak tidak dapat melampaui fantasi seperti itu secara realistis. Pihak yang paling tergugah adalah orang tua. Orang tua lebih memiliki kekuasaan terhadap anaknya. Disamping ketakutannya pada penurunan kualitas intragenerasi, orang tua juga menginginkan anaknya minimal untuk mempertahankan kejayaan orang tua atau maksimal mengubah nasib keluarga pada generasi selanjutnya. Karena itu, jarang anak-anak bersikap agresif terhadap pendidikan kecuali orang tua mereka yang sangat ambisius. 
Pencitraan-pencitraan yang diberikan oleh iklan disini dapat berupa ekspresi yang meskipun tak lazim dan berlebihan, tetapi banyak diinginkan orang. Misalnya seperti gambar - gambar berikut:

Gambar 7

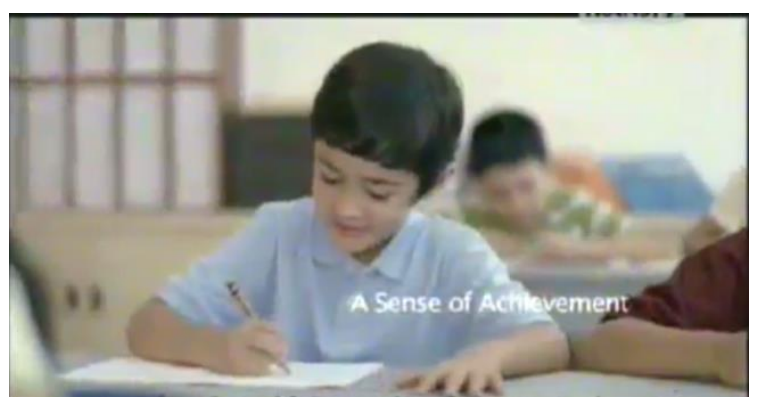

Gambar 8

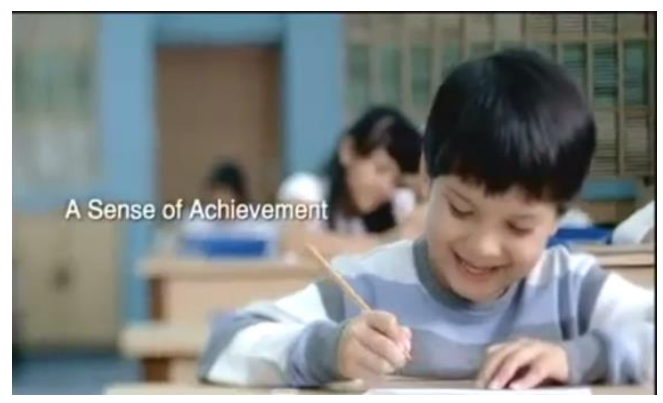

Gambar 9

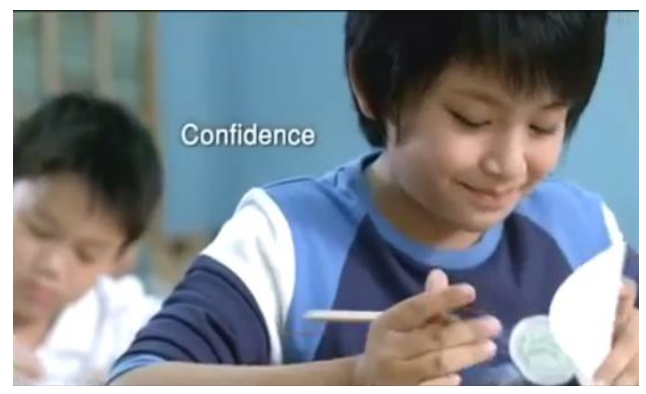

*gambar 7 diambil dari potongan iklan KUMON 2012, gambar 8 da 9 dari potongan iklan KUMON 2013

Ketiga gambar diatas adalah gambaran tentang sensasi belajar dimulai dari rasa percaya diri hingga perasaan pencapaian yang didapat. Penanda-penanda yang paling mencolok adalah senyum dari anak-anak. Hal ini memunculkan simpulan: Senyum seperti itu tak lazim muncul pada niat anak-anak terutama dalam belajar dan cara mengajar yang memiliki model yang membosankan. Bahkan dengan cara yang menyenangkan pun belum tentu menumbuhkan interest belajar pada anak. Namun, KUMON menampilkan citra-citra seperti kepercayaan diri dan senyuman anak-anak pada saat mengerjakan soal demi menarik perhatian orang tua yang memiliki keinginan agar anaknya gemar dan semangat belajar.

Terdapat hubungan kausal antara teknik penarik perhatian fisik dengan penarik perhatian emosi. Pertama, dikarenakan semangat belajar seperti yang dicitrakan dalam gambar itu tidaklah demikian pada kenyataannya, namun tetap ditampilkan untuk mendukung apa yang disukai khalayak (terutama orang tua). Kedua, jika memang pencitraan tersebut tidak ada 
dalam dunia nyata, dan karena pencitraan itu di sisi lain merupakan apa yang banyak dïnginkan orang tua, maka suatu hal yang tak lazim itupun tetap ingin diwujudkan dalam kenyataan baik dari usaha lembaga maupun khalayak sendiri.

Baudrillard menyajikan logika yang menarik mengenai kebenaran iklan. Menurutnya, iklan tidak membohongi khalayak, melainkan melampaui kebenaran dan kesalahan. Ia mengutip Boorstin bahwa pengiklan tidak sepenuhnya berbohong, tetapi hanya menggunakan persuasi yang tidak benar tetapi juga tidak salah (2011:159). Hal ini terkait dengan hubungan antara penarik perhatian fisik dan penarik perhatian emosi yang sebenarnya bertentangan; antara yang tidak mungkin dan yang disuka menjadi satu. Iklan memanfaatkan keinginan khalayak bahkan jika itu hanya sebuah ketidakmungkinan. Williamson menyatakan bahwa dalam proses periklanan pun terjadi demikian. Proses periklanan menyuguhkan kepada kita (khalayak) tentang imaji diri kita (khalayak) yang mungkin dicita-citakan, namun tidak pernah kita capai (2007:91).

\section{Ideologi dalam Slogan}

Gambar 10

Gambar 11
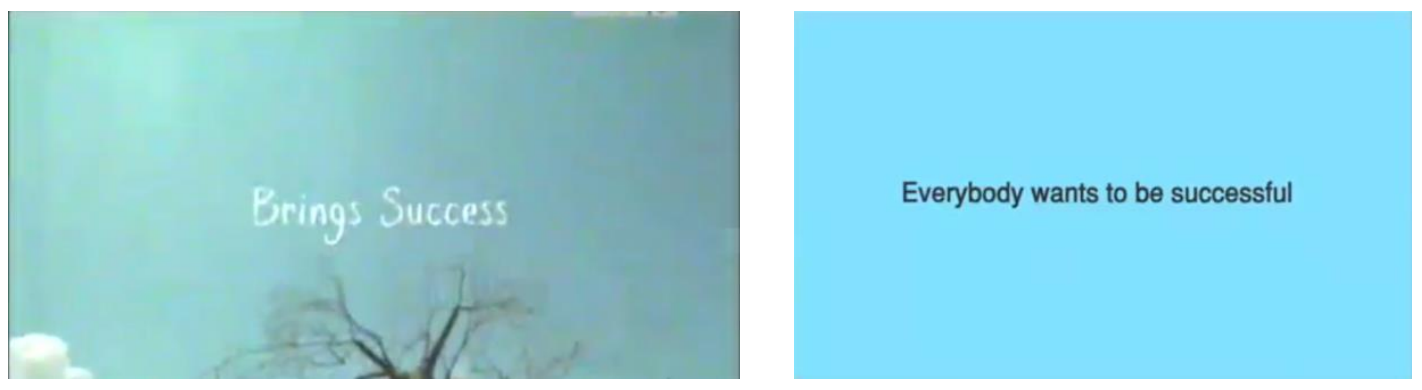

Gambar 12

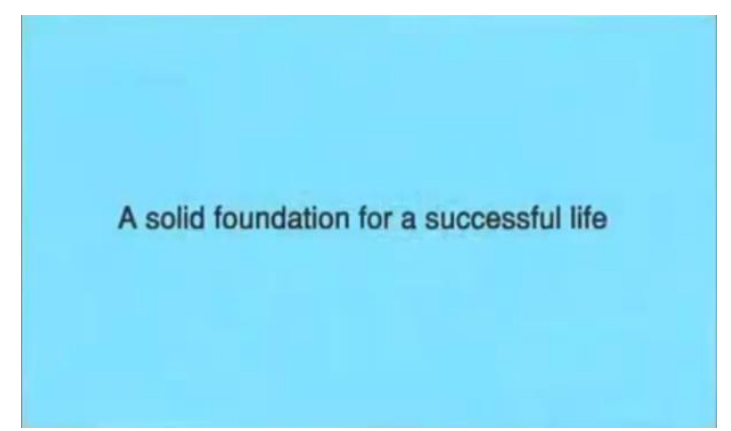

Iklan kurang mengena kiranya jika tanpa slogan dan klaim. Slogan merupakan sebuah kalimat positioning yang mudah dïngat, kalimatnya pendek, dan menjadi ciri khas (Ihza, 2013:42). "Bring Succes" pada gambar 10 adalah slogan KUMON sering muncul dalam akhir 
iklan. Slogan ini menekankan bahwa KUMON dapat membawa manusia menuju kesuksesan, yakni kesuksesan yang telah disortir seperti cita-cita tertentu yang telah dibahas diatas.

Terdapat kalimat ideologis yang dapat berupa klaim sekaligus ajakan dalam gambar 11 . Kalimat yang berbunyi "Everybody wants to be successful" (setiap orang ingin sukses) medorong klaim KUMON bahwa semua orang menginginkan kesuksesan. Klaim tersebut dapat berupa benar-benar fakta atau hanya untuk menciptakan fakta bahwa semua orang menginginkan kesuksesan. Penekanan pada kata "everybody..." seolah menyiratkan bahwa kebutuhan untuk sukses adalah universal. Klaim tersebut menurut Terry Eagleton meuniversal-kan keyakinan untuk membuatnya jelas dan tampak tak terelakkan (1991:5). Baudrillard juga menyatakan bahwa media massa berfungsi untuk menetralkan ciri khas nyata, unik, peristiwa dunia, untuk menggantikan dunia yang beragam dengan dunia yang homogen... Iklan pada dasarnya memaksakan konsensus dengan semua individu (Baudrillard, 2011:154156). Ungkapan yang universal secara tak sadar membuat seluruh kehidupan sosial seolah memiliki tujuan yang satu. Kesadaran manusia diubah dengan dibuat percaya atau minimal disuguhkan pernyataan yang membuatnya terdorong -- jika tidak dapat dikata mengikuti -seseorang akan merasa tertinggal apabila tidak menjadi sukses.

Dalam ilmu tentang tanda (semiologi), klaim-klaim seperti diatas disebut juga argumenta. Argumenta berasal dari kata argumentum yang menurut Cicero berarti 'hal fiktif yang mungkin bisa terjadi' atau 'gagasan yang kelihatannya benar yang digunakan untuk meyakinkan orang'. Menurut Quantilianus, argumentum berarti cara pembuktian suatu hal dengan cara yang lain untuk mengonformasi hal yang meragukan dengan menggunakan suatu hal yang sudah pasti (Barthes, 2007:145).

KUMON mencoba memastikan apa yang diberinya (yakni kesuksesan) dengan memakai klaim universal bahwa setiap orang membutuhkan dan menginginkan kesuksesan. Kata-kata dan slogan dihubungkan dengan penanda-penanda lain dalam scene iklan yang lain yang juga memiliki konotasi sehingga konotasi-konotasinya saling berhubungan. Dengan cara ini, KUMON melakukan sekali dayung tiga pulau terlampaui. Di satu sisi, menyesuaikan dengan kondisi global yakni kebutuhan untuk sukses, di sisi lain KUMON mencoba memberi gambaran yang 'jelas' tentang sukses yang ideal.

Gambar 12 memiliki makna yang mirip dengan gambar 10. Merupakan klaim mengenai keunggulan lembaga (dalam hal ini adalah KUMON). Jika pada gambar 10 KUMON mengklaim dapat membawa seseorang pada kesuksesan, maka gambar 12 lebih kepada klaim bahwa KUMON adalah lembaga yang tepat untuk mendukung gambar 10. KUMON mengaku merupakan lembaga (foundation) yang memberi kehidupan yang sukses (successfully life). 
Mitos yang dimunculkan gambar 10 dan 12 lebih kepada kemampuan KUMON dalam memberikan apa yang sistem kultural minta (kebutuhan untuk sukses pada seseorang). Sedangkan, pada gambar 11 lebih kepada dukungan fakta bahwa kesuksesan itu universal, dïnginkan setiap orang, dan mutlak, meskipun bisa jadi merupakan persuasi KUMON sendiri dengan mengatasnamakan 'setiap orang' agar orang mencari kesuksesan yang digambarkan dengan cara tertentu, disamping juga agar lembaganya laku didatangi. Selain itu, KUMON seolah mewakili seluruh dunia bahwa sukses dan dirinya sendiri (lembaga KUMON) adalah memiliki hubungan.

\section{Mitos Egalitarianisme}

Melalui klaim ideologis dan argumentum, selanjutnya iklan KUMON memunculkan mitos tentang kesamaan hak. Sama halnya klaim bahwa manusia menginginkan kebahagiaan. Kebahagiaan bukanlah hal yang alami melainkan terjadi secar socio-historis yang diterima masyarakat modern (Baudrillard, 2011:43). Kesuksesan terutama yang bersifat material bukanlah kebutuhan yang murni alami, melainkan diciptakan. Semua manusia menginginkan uang yang padahal merupakan kebutuhan yang diciptakan oleh ekonomi modern (Marx dalam Fromm, 2004:186).

Kebutuhan-kebutuhan yang diciptakan oleh ideologi ini secara manifes hanya sebagai penyebaran komoditi, tetapi secara laten menyusupkan ide-ide ke dalam seluruh lapisan masyarakat tak terkecuali masyarakat yang serba kekuarangan. Iklan KUMON dapat dikatakan sebagai iklan borjuis yang menggunakan ideologi borjuis pula. Dapat dilihat dari anak-anak yang dijadikan sebagai bintang iklannya, warna kulitnya, cara berpakaiannya, dan sikapnya. Jarang ada kaum marjinal yang berperilaku seperti itu. Dengan demikian, apa yang dikatakan Barthes adalah tepat. Barthes menyatakan bahwa ideologi borjuis bekerja melalui borjuasi, dan borjuasi mendukung ilusi peniadaan kelas (2009:205). Sebuah pengetahuan yang menampilkan ilusi sosial yang nyata (social necessary illusion) (Eagleton, 1991:2). Mampu atau tidak mampu seseorang dalam mencapai tujuannya, mitos memaksa manusia untuk mengarah pada tujuan yang sama; sukses materiil, yang sebenarnya merupakan ilusi dan bertentangan dengan kondisi manusia.

\section{Mata Pelajaran dan Doktrin Global}

Menganalisis iklan KUMON kurang afdol rasanya jika tidak menghubungkannya dengan aspek lain seperti mata pelajaran yang menjadi andalan $K U M O N$; matematika dan bahasa Inggris. Tentu disamping kebutuhan akademis, kebutuhan sosio-kultural merupakan dorongan yang lebih tinggi sebagai asalan mengapa KUMON tidak memasukkan ilmu 
pengetahuan lain seperti halnya lembaga-lembaga bimbingan lain. Padahal, lembaga KUMON cukup besar untuk mengajarkan materi lain selain dua ilmu andalannya.

Globalisasi adalah faktor pertama yang penulis ajukan sebagai alasan kritik terhadap pemilihan mata pelajaran yang dipilih KUMON. Terutama materi bahasa Inggris, materi tersebut sudah menjadi kebutuhan internasional baik oleh orang-orang yang bekerja dalam industri dan juga kesenian (bintang film dan sebagainya). Globalisasi menuntun segalanya menjadi internasional; hubungan ekonomi, politik, sosial dan budaya (Joseph, edukasi.kompasiana.com 2013). Sekalipun tujuannya untuk menerobos batas-batas negara, yang terjadi malah terjadi penciptaan bahasa baru; bahasa global. Hal ini memiliki dampak positif dan negatif. Positif karena sangat membantu terjalinnya hubungan internasional, negatif karena terdapat usaha laten penyingkiran bahasa lokal yang berimbas pada budaya sekaligus. Efek negatif adalah efek terbesar karena didukung oleh tekanan global yang menjadi keharusan.

Matematika sebagai induk dari segala ilmu alam dan ilmu industri menjadi legitimate karena era industri dan era teknologi. Kondisi ini telah diramalkan oleh Lyotard bahwa disiplin ilmu seperti bahasa, matematika, dan cybernetic akan menjadi prioritas dalam pendidikan dalam memenuhi fungsi pragmatik institusi (2009, 146-147). Bukan hanya fungsi pragmatik dalam artian kegunaan dan tuntutan spesialisasi dunia industri era informasi, tetapi juga pragmatik dalam artian perolehan pendapatan ekonomis yang diharapkan.

Pemilihan mata pelajaran pokok KUMON merupakan ideologi. Penentuannya didasarkan doktrin global dan menyesuaikan diri terhadapnya. Soyomukti menyatakan bahwa globalisasi membawa doktrin yang membentuk masyarakat, peserta didik, dan pengajar tidak luput dari doktrin global. Sistem dan budaya pendidikan yang berkembang juga telah terhegemoni oleh perkembangan globalisasi (2010:43). Budaya pendidikan tidak hanya bisa dilihat di lingkungan sekolah, tetapi juga orientasi masyarakat luas yang bahkan belum sempat mengetahui hakikat pendidikan (pertukaran pengetahuan) dan tujuannya. Ditambah dengan penggunaan iklan, doktrin semakin meluas kepada siapa saja yang menyaksikan iklan yang sedang tayang.

\section{Orientasi Ekonomis dalam Iklan KUMON: Kapitalisme Masih Bersalah}

Seperti yang telah dianalisis bahwasannya KUMON sering menekankan pentingnya beberapa profesi di era industri serta secara laten mendorong mengakarnya orientasi pragmatis dalam memandang kegunaan pendidikan. Pendidikan yang berfungsi sebagai penyalur dan bertukar ilmu pada dasarnya masih menjadi tujuan utama, tetapi bagaimana bila dunia menuntut hal lain seperti kekayaan, pengembalian modal selama menghidupi anak, dan 
pencapaian yang mendekati ketamakan? Tuntutan ekonomi tidak hanya memaksa para pengusaha kapitalis dalam menaikkan keuntungan dan modal, melainkan juga menuntut segala aspek yang berhubungan dengannya. Dalam kasus ini pendidikan disesuaikan dengan kondisi dunia yang serba mendasarkan diri pada kekayaan, kepemilikian, dan ketamakan dibalik nilai moral seperti 'menjadi orang yang berhasil' dalam hidup.

Kondisi era late capitalism dan post-modern ini menyebabkan dorongan ekonomi tidak berkutat di ranah ekonomi. Sebagaimana menurut Habermas bahwa kesuksesan pekerjaan yang bisa dicapai dengan cara menempuh sekolah formal mengambil alih kesuksesan di dalam pasar, (hal ini didukung oleh) perkembangan yang sinkron antara sistem pendidikan dan pekerjaan (2004:247). Bukan hanya sistem dalam pendidikan, melainkan sistem sosial yang menuntut manusia untuk adaptif terhadap lingkungan dan perkembangan jaman. Tekanan-tekanan sosial yang memberi penderitaan dimanfaatkan oleh iklan sebagai keadaan yang harus diberi harapan sekalipun mustahil harapan itu dicapai.

Dalam hal ini, bukan hanya pendidikan yang berorientasi pragmatis. Masyarakatlah yang nyata memiliki sifat pragmatis tinggi. Oleh karenanya, iklan menyuguhkan apa yang diinginkan masyarakat. Sekalipun, kondisi masyarakat yang pragmatis ini sebenarnya juga bentukan peradaban modern yang akumulatif dan perhitungan. Kondisi-kondisi dan reproduksi kultural dalam iklan saling mengalami hubungan resiprokal. Iklan dan khalayak bisa jadi tersangka sekaligus dalam membentuk peradaban. Tetapi perlu menjadi sebuah catatan bahwa keinginan manusia itu rawan terdistorsi dan direduksi oleh pembuat wacana dan para pencipta mitos. Distorsi inilah yang membuat tidak ditemukan jawaban pasti apakah iklan benar-benar memengaruhi khalayak atau khalayak yang menyebabkan iklan memberikan apa yang khalayak inginkan.

Oleh karena iklan merupakan alat propaganda dan alat bantu kapitalis yang masih menjadi yang terakhir, kiranya kapitalis masih dapat disalahkan. Karena kapitalisme-lah yang menyebabkan iklan muncul demi penyebarluasan komoditas baik material maupun ide. Orientasi masyarakat yang ekonomis adalah akibat dari peradaban modern yang terus dipelihara. Cara pemeliharaan ini dilakukan melalui iklan. Jadi, iklan tidaklah menjadi penentu kesadaran, melainkan melanggenggkan kesadaran palsu yang muncul sejak era kapitalis awal (di jaman dimana Marx mengkritiknyadalam Economy and Philosophical Manuscript).

Oleh karena doktrin pragmatis telah meluas, segala yang ada baik sosial, budaya, politik, bahkan pendidikan haruslah memiliki kegunaan dan keuntungan ekonomis. Diluar itu maka dianggap kurang bermanfaat. Watak masyarakat dibentuk untuk mengejar profit bukan hanya di dunia perdagangan, tetapi juga di dunia pendidikan. Anak merupakan objek investasi 
dan sekolah adalah sarananya. Banyak orang tua memiliki persepsi bahwa sekolah adalah investasi masa depan dan sepenuhnya dipahami secara ekonomi (Nuryanto, 2010:82). Selanjutnya, murid atau anak-anak menjadi konsumen diajarkan untuk menyesuaikan keinginan mereka dengan nilai yang dapat dipasarkan (Illich, 2008:56).

Cita-cita anak yang ditampilkan iklan KUMON tidak dapat dilepaskan dari kultur dan wacana yang merupakan konotasi yang ada di belakangnya. Kultur tersebut seperi yang banyak diakui orang yakni tentang kesejahteraan ekonomi. Tidak ada yang benar-benar murni orang tua yang menyekolahkan anaknya dengan tujuan akademik. Dengan dalih dan pujian 'pintar' pun tidak cukup. Pintar yang dimaksud kebanyakan orang tua adalah yang mendapatkan pekerjaan yang mapan, bukan dari kemampuan bakat dan kreativitas murni anak. Dengan demikian, penulis bisa langsung mengkritik Fukuyama yang menyatakan bahwa tanpa pelbagai kedudukan yang membuka bakat ketimbang privelis, masyarakat kapitalis tidak akan berhasil seperti yang mereka inginkan (2004:445). Kenyataannya, kebutuhan tentang bakat itu hanyalah mitos. Bakat akan lenyap mejadi orientasi seiring kebutuhan pekerjaan mapan dibutuhkan. Jika pendapat Fukuyama bisa disetujui, itu hanya berlaku pada konteks negara maju yang dimana ia tinggal. Sedangkan, di negara berkembang seperti Indonesia yang kesadaran pendidikannya masih kurang dibandingkan kesadaran ekonominya, maka akan berbeda cerita.

Iklan KUMON mereduksi keberhasilan seseorang dalam batas-batas. Hal inilah yang merupakan tipe wicaranya (mitosnya). Alternatif kesuksesan seperti spriritual, pergerakan sosial, digantikan dengan kesuksesan yang bernilai material (yang notabene memang menjadi keinginan hampir setiap orang).

\section{Ilmu Alam dan Anti Ilmu Sosial}

Sebagaimana yang telah dijelaskan sebelumnya bahwa ilmu alam mendapat legitimasi penuh di era teknologi informasi dan industri. Hal ini menimbulkan efek yang tidak langsung pada perkembangan ilmu pengetahuan. Masyarakat akan lebih memilih ilmu pengetahuan yang lebih menjanjikan. Paradoks liberalisme inilah yang melahirkan kecenderungan pemisahan pendidikan dari urusan politik dan budaya (Fakih, 2010: 26). Dengan menekankan pada pentingnya ilmu alam beserta kemungkinan-kemungkinan hasil yang didapat, iklan KUMON secara tidak langsung menanamkan pemikiran bahwa ilmu lain seperti ilmu sosial tidak akan menghasilkan kegunaan apa-apa dalam masyarakat era teknologi, informasi, dan industri.

Ilmu-ilmu kemanusiaan yang humanis semakin tersingkir karena memang kegunaan pragmatisnya lebih rendah dibanding ilmu alam yang berkait erat dengan institusi industri dan teknologi jaman modern. Dengan keadaan yang tidak mendukung berkembang hidupnya ilmu sosial, atau minimal menjadikan ilmu sosial itu sendiri sebagai instrumen dalam perkembangan 
teknologi industri, maka ilmu sosial perlahan-lahan mati. Mati karena minimnya kegunaan pragmatiknya, dan mati karena keadaan yang membuatnya terdistorsi sehingga kehilangan kekuatannya, selain bahasa kritis yang jarang diterima khalayak awam.

Iklan melakukan propaganda sama seperti yang dilakukan abad Pencerahan. Iklan melahirkan kembali semangat dalam batas tertentu tetapi dengan penekanan yang berlebihan. Seperti yang dilakukan iklan KUMON, membatasi definisi kesuksesan dan melakukan doktrin pentingnya ilmu alam dan ilmu bahasa global dengan cara yang berulang-ulang.

\section{Masa Depan: Kebutuhan atau Persuasi?}

Mobilitias sosial berhubungan erat dengan bayang-bayang masa depan. Masa depan identik dengan transformasi hidup dari yang belum layak menjadi layak atau dari yang belum sepenuhnya baik menjadi lebih baik. Akan tetapi, darimana landasan berpikir bahwa manusia harus mendapatkan masa depan yang baik. Banyak landasan dan bisa jadi kitab suci ataupun tutur budaya. Namun, di era seperti sekarang iklan menjadi kiblat baru dan menjadi sumber kesadaran baru atau seperti istilah yang digunakan Stuart Ewen; captain of consciousness. Herbert Marcuse dalam memandang media massa pun demikian, bahwasannya kebudayaan industri maju bersifat lebih ideologis daripada kebudayaan yang mendahuluinya (Marcuse, 2002:17). Industri maju ini pada akhirnya bukan hanya industri barang dan jasa melainkan juga industrialisasi pikiran. Media (iklan) tidak lebih sebagai tools of the mind-making industry dan eksploitasi pikiran (Latif \& Ibrahim dalam Suyoto Ed, 1994:241). Pada akhirnya, kebutuhan itu tidak datang dari keinginan manusia, melainkan bentukan dari suatu rezim tertentu agar manusia merasa membutuhkan.

Sebelum membahas iklan, peneliti akan lebih fokus kepada kritik atas fungsi pendidikan. Ivan Illich adalah yang paling keras menentang adanya sekolah. Disini peneliti tidak menjadikan sekolah sebagai sasaran kritik dikarenakan KUMON sendiri adalah lembaga bimbingan belajar nonformal. Akan tetapi, pemikiran Illich tentang sekolah dapat berguna untuk menganalisa dan mengkritik $K U M O N$ sebagai lembaga pendidikan (nonformal) pada sisi tertentu.

Iklan KUMON menampilkan beberapa citra yang mengkonotasikan masa depan bahkan hampir semua scene bercerita akan hal itu. Iklan KUMON menawarkan beberapa jenis pekerjaan yang dikaitkan dengan warna memiliki makna serta beberapa hubungan dengan realitas. Semua itu adalah narasi-narasi tentang masa depan. Hal ini seperti yang dikatakan Illich bahwa semua sekolah mengatakan bahwa mereka (sekolah) membentuk manusia untuk masa depan (Illich, 2009:523). Bahkan untuk dalam gambar 11 iklan mengklaim bahwa apa yang $K U M O N$ tawarkan adalah keinginan setiap orang. 
Terkait dengan pekerjaan atau profesi masa depan, sekolah atau dalam kasus yang peneliti kaji adalah lembaga pendidikan nonformal menawarkan suatu hal yang berhubungan dengan kehidupan layak. Kehidupan layak ini memang diinginkan setiap orang akan tetapi, perlu diperjelas bahwa bahasa seperti itu adalah sangat ideologis. Hanya saja tertutupi oleh keahlian iklan dalam menyampaikan hal yang bersifat mitos yang seakan-akan benar-benar alamiah. Kehidupan layak sekarang tidak bisa dilihat secara kualitas dan selalu terkait dengan kuantitas atau pengukuran-pengukuran seperti kategori pendapatan atau kehormatan. Nampak jelas pengukuran ini dalam iklan $K U M O N$ selalu menampilkan profesi-profesi yang tidak biasa dan prestisius dan berhubungan dengan derajat manusia.

Sekolah-sekolah menawarkan pendidikan untuk hidup dan bukan pendidikan dalam kehidupan sehari-hari (Illich, 2009:523). Terjadi hubungan erat manakala lembaga bimbingan belajar nonformal dan sekolah bertemu dengan pemikiran-pemikiran masyarakat yang umum terkait dengan tujuan pragmatis. Ketiganya merupakan suatu hal yang telah mapan dalam masyarakat bahwa apapun bentuk pendidikan salah satunya KUMON secara denotatif adalah untuk mencerdaskan. Akan tetapi, secara konotatif pemikiran tersebut hanya menciptakan suatu kemutlakan bahwa sekolah atau berpendidikan adalah untuk mencari kerja dan kerja adalah kelayakan hidup. Kehidupan layak merupakan suatu tujuan yang harus dicapai dan menjadi keinginan pragmatis baik itu bagi orang banyak maupun dari ide pengiklan untuk membujuk khalayak.

Pada akhirnya, bukan hanya sekolah saja yang menjadi sumber dari mitos-mitos kesuksesan. Di era sekarang ini dengan berkembangnya alternatif-alternatif dan koreksikoreksi realitas mengakibatkan banyaknya lembaga-lembaga yang menawarkan hal yang sama yakni kesuksesan. Hanya saja, perbedaan terletak pada tingkat formalitas. Dapat dilihat bahwa ketika lembaga formal 'seolah' tidak dapat memberi jaminan kesuksesan di masa mendatang, sang perayu baru dalam hal ini lembaga alternatif, salah satunya adalah KUMON datang mengisi harapan-harapan. Illich menyatakan bahwa pembaharu pendidikan seperti itu adalah berbahaya. Pendidikan seperti itu yakin bahwa pengetahuan bisa diproduksi dan dijual di pasar terbuka (Illich, 2009:523). Penciptaan budaya pragmatisme dibarengi pragmatisme lembaga itu sendiri. Pendidikan jadi semakin hilang kemuliaannya karena tujuan ekonomis.

Jika pengetahuan yang diperjual belikan saja adalah bahaya menurut Illich, lantas bagaimana dengan iklan KUMON. Iklan tersebut menawarkan janji-janji keuntungan apa yang akan didapat di masa mendatang setelah belajar. Hal ini berarti bukan hanya pembaharu pendidikan berbahaya karena jual beli pengetahuan, melainkan juga karena suatu lembaga juga menghasut, merayu, dan membujuk banyak orang dengan suatu hal yang menjadi keuntungan 
nantinya. Pendidikan disamping menjadi objek dagangan juga dijadikan sarana menuju perolehan material layaknya suatu penanaman saham.

Iklan KUMON seperti halnya iklan yang lain yang sangat persuasif mengakibatkan adanya permintaan. Permintaan yang mana seperti yang dikatakan Illich muncul akibat dari sekolah yang memunculkan mitos tentang konsumsi tanpa akhir. Dalam konteks di masa Illich hidup, sekolah mendasarkan pada keyakinan bahwa suatu proses pastilah menghasilkan suatu nilai dan karena itu, produksi pasti menghasilkan permintaan (2009:528). Permintaan ini jika dikorelasikan dengan temuan peneliti dan konteks yang sekarang berkembang adalah secara struktur sama seperti yang terjadi di masa Illich. Hanya saja, saat ini jauh lebih kompleks dimana permintaan-permintaan bukan saja dikarenakan adanya produksi dan kebutuhan, melainkan juga pembentukan permintaan itu sendiri. Prinsip diatas mengambil prinsip iklan dimana khalayak dibuat untuk ingin bukan karena memang ingin. Tidak peduli dari kelas mana dan keluarga dengan kondisi ekonomi seperti apa, semuanya menjadi sasaran.

Kendati banyak orang memang menginginkan kesuksesan akan tetapi, iklan menyajikannya untuk lebih menggugah lagi, seperti ketika sukses hanya digambarkan dengan profesi tertentu yang menjanjikan. Jika Illich menyatakan bahwa sekolah membuat mereka (masyarakat) membutuhkannya, maka KUMON tidak melakukannya secara langsung bahwa lembaga tersebut dibutuhkan. KUMON menyajikan apa yang dibutuhkan orang banyak dengan tidak menyinggung terlalu banyak tentang lembaga itu sendiri. KUMON lebih menunjukkan bahwa kesuksesan dalam gambaran tertentulah yang menjadi kebutuhan khalayak. Dalam hal ini, Marcuse benar bahwa industri kebudayaan sekarang tidak hanya informatif tetapi juga sangat ideologis.

\section{Mitos dan Narasi Besar Kesuksesan}

Mitos disampaikan melalui gambaran-gambaran bineri dan penekanan berulang-ulang sebagai pengetahuan yang diperuntukkan bagi manusia. Oleh karena mitos di era kontemporer ini identik dengan mitos global, maka mitos-mitos juga merupakan narasi besar.

Kesuksesan adalah termasuk perihal yang menjadi cerita besar abad ekonomi modern. Kesuksesan menjadi orientasi dan pencapaian utama masyarakat kontemporer. Perolehannya menghubungkan nilai guna dan nilai tanda sekaligus. Disamping pemenuhan kebutuhan juga terdapat usaha pemenuhan prestige.

Iklan KUMON menebar pengetahuan melalui bahasa dan citra visual. Pengetahuan yang diberikan bukan hanya diberikan semata-mata, tetapi disajikan dengan klaim yang terrasa sangat pasti sesuai kode budaya. pengetahuan yang dilegitimasi ini melalui kerangka ceritacerita besar (Lubis, 2014:136). Cerita-cerita besar ini adalah kode budaya yang menjadi suara 
kolektif yang telah mengakar dan terakui dalam pemahaman masyarakat. Iklan membantu melegitimasi lebih lanjut mengenai pengetahuan tadi.

Manusia membutuhkan kesuksesan dalam arti keberhasilan yang cukup dan tidak dengan gambaran berlebih. Namun, iklan menggambarkannya secara berlebih kendati iklan menyetujui apa yang ada dalam pemikiran masyarakat. Terutama dalam wacana pendidikan yang terjadi pembalikan pemahaman atau terjadi pemahaman yang salah. Pendidikan (sekolah dan sejenisnya) yang seharusnya menjadi sarana mencapai kemandirian bangsa, malah berfungsi untuk meningkatkan status sosial (Sumadi dalam Arif dkk, 2014:59). KUMON menebar pengetahuan dengan bantuan media massa yang dilihat segala lapisan masyarakat yang memiliki kemungkinan terpengaruh (baik langsung maupun tidak langsung).

Sebagai media yang terdapat kecenderungan ideologis, sama seperti halnya kemunculan positivisme, jaman modern memiliki kecenderungan penciptaan narasi besar. Pemahaman manusia harus universal dan tidak menerima narasi kecil atau "the other". Kesuksesan menjadi mitos dan narasi besar abad ekonomi dan hingga kini ketika kebutuhan mobilitas sosial dan kekayaan menjadi tujuan utama manusia. Bahkan lembaga revolusioner seperti pendidikan pun 'termakan' narasi besar. Pendidikan yang berguna sebagai transformasi sosial seperti pada jaman Boedi Oetomo berubah menjadi sarana perolehan tujuan pragmatis yang minim nalar kritis.

Penulis (dengan tidak mengurangi rasa hormat) mengkritik KUMON karena telah menayangkan iklan yang dapat dibilang baik tapi rawan unsur ideologi dan pendangkalan pemahaman masyarakat. Terutama terkait dengan cara memandang pendidikan sebagai tujuan dan sarana untuk perubahan baik individu maupun kepentingan bersama. Ditambah, pengaruhnya pada perkembangan ilmu pengetahuan bangsa yang menjadi menurun karena banyaknya masyarakat mencari keuntungan materiil semata tanpa mempedulikan kemajuan akademik. Serta, membuat penilaian-penilaian sempit tentang ilmu pengetahuan mana yang 'berguna' dan yang tidak. Sehingga, bukan hanya menjadikan masyarakat berpikir bahwa sekolah atau lembaga pendidikan sebagai lembaga mobilisasi sosial, melainkan juga pada tahap selanjutnya menyingkirkan ilmu pengetahuan yang tidak bernilai pragmatis. Narasi besar cenderung menindas narasi kecil.

\section{Kesimpulan}

Iklan KUMON adalah iklan ideologis yang menyampaikan pemahaman dengan sistem penandaan atau tipe wicaranya. KUMON mereduksi 'kesuksesan' semata pada cita-cita tertentu yang memiliki kode budaya yang mendekati pada pemahaman pragmatis masyarakat, 
perolehan keuntungan melalui pendidikan, dan menjadikan pendidikan hanya sebagai sarana memperolehnya. Iklan KUMON juga melegitimasi ilmu pengetahuan yang bernilai pragmatis dan menghubungkannya dengan 'kesuksesan' dan mengklaim bahwa hal itu adalah universal dibutuhkan manusia.

Serupa dengan mitos-mitos kuno, mitos kontemporer seperti iklan juga mewacanakan berbagai hal melalui tipe wicara tertentu. Disamping memberi pengetahuan, mempersempitnya, dan juga membujuk, iklan meskipun pengaruhnya tidak terlalu kuat dalam hal promosi lembaga tetap saja dapat merubah cara pandang masyarakat. Setiap orang tidak mungkin dapat memasukkan anaknya belajar di KUMON, tetapi setiap orang akan mencari tempat belajar yang lain. Karena, setiap orang dapat terpengaruh oleh kode-kode budaya mereka sendiri yang disisipkan dalam iklan, bukan oleh lembaga yang sedang melakukan promosi.

\section{Referensi}

Aprilia, Dwi Ratna. 2005. Iklan dan Budaya Popular: Pembentukan Identitas ideologis Kecantikan Perempuan oleh iklan. (online). Jurnal Ilmu Komunikasi. Vol 1 nomor 2, Juni 2005: 41-68. Diakses dari portal garuda pada 26 Agustus 2013

Arif, Mukhrizal, et al. 2014. Pendidikan Posmodernisme. Bandung: Ar-Ruzz Media

Barthes, Roland. 2007. Petualangan Semiologi. Yogyakarta: Pustaka Pelajar

Barthes, Roland. 2009. Mitologi. Yogyakarta: Kreasi Wacana

Barthes, Roland. 2010. Imaji Musik Teks. Yogyakarta: Jalasutra

Barthes, Roland . 2012. Elemen-elemen Semiologi. Yogyakarta: IRCiSoD

Baudrillard, Jean. 2011. Masyarakat Konsumsi. Yogyakarta: Kreasi Wacana

Budiman, Kris. 1999. Kosa Semiotika. Jakarta: LKiS

Durkheim, Emile. 2011. The Elementary Forms of The Religious Life: Sejarah Bentuk-Bentuk Agama yang Paling Dasar. Yogyakarta: IRCiSoD

Eagleton, Terry. 1991. Ideology: An Introduction. Newyork: Verso

Fakih Mansour et al. 2010. Pendidikan Popular: Membangun Kesadaran Kritis. Yogyakarta: INSIST Press

Featherstone, Mike. 2008. Posmodernisme dan Budaya Konsumen. Yogyakarta: Pustaka Pelajar

Fiske, John. 2012. Pengantar Ilmu Komunikasi. Jakarta: RajaGrafindo

Freire, Paulo et al. 2009. Menggugat Pendidikan: Fundamentalis, Konservatif, Liberal, Anarkis. Editor: Omi Intan Naomi. Yogyakarta: Pustaka Pelajar 
Fromm, Erich. 2008. Konsep Manusia Menurut Marx. Yogyakarta: Pustaka Pelajar

Fukuyama, Francis. 2004. The End of History and The Last Man. Yogyakarta: Qalam

Habermas, Jurgen. 2004. Krisis Legitimasi. Yogyakarta: Qalam

Horkheimer, Max \& T. W. Adorno. 2002. Dialektika Pencerahan. Yogyakarta: IRCiSoD

Ihza, Yustiman. 2013. Bujuk Rayu Konsumerisme. Depok: Linea Pustaka

Illich, Ivan. 2008. Bebaskan Masyarakat Dari Belenggu Sekolah. Jakarta: Yayasan Obor Indonesia

Joshep, Yohanes Philipus. 2013. Bahasa Inggris sebagai Tuntutan Era Globalisasi. (online). Diakses dari http://edukasi.kompasiana.com/2013/06/16/bahasa-inggris-sebagaituntutan-era-globalisasi-565533.html pada 25 Nopember 2013

Kellner, Douglas. 2002. Theorizing Globalization. (online). Sociological Theory, vol 20 No. 3. Wiley Blacwell. Diakses dari http://artsvylle.com/files/docs/theorizing\%20globaliz taion\%20-\%20ArtsVylle.pdf pada 31 Agustus 2013

Lubis, Akhyar Yusuf. 2014. Teori dan Metodologi Ilmu Pengetahuan Sosial Budaya Kontemporer. Jakarta: Rajawali

Lyotard, J. F. 2009. Kondisi Posmodern: Suatu Laporan mengenai Pengetahuan. Surabaya: Selasar

Marcuse, Herbert. 2002. Manusia Satu Dimensi. Yogyakarta: Bentang

Martono, Nanang. 2012. Kekerasan Simbolik di Sekolah: Sebuah ide Sosiologi Pendidikan Pierre Bourdieu. Jakarta: Raja Grafindo

Nuryanto, M Agus. 2011. Mazhab Pendidikan Kritis. Sleman: Resist Book

Rusmana, Dadan. 2014. Filsafat Semiotika. Bandung: Pustaka Setia

Sarup, Madan. 2010. Panduan Pengantar untuk Memahami Poststrukturalisme dan Posmodernisme. Yogyakarta: Jalasutra

Sobur, Alex. 2009. Semiotika Komunikasi. Bandung: Rosdakarya

Soyomukti, Nurani. 2010. Pendidikan Berperspektif Globalisasi. Yogyakarta: Ar-Ruzz Media Suyanto, Bagong. 2013. Sosiologi Ekonomi: Kapitalisme dan Konsumsi di Era Masyarakat Post-modern. Yogyakarta: Kencana

Suyoto (Ed) et al. 1994. Postmodern dan Masa Depan Peradaban. Yogyakarta: Aditya Media Takwin, Bagus. 2009. Akar-Akar Ideologi: Pengantar Kajian Konsep Ideologi dari Plato hingga Bourdieu. Yogyakarta: Jalasutra

Trifonas, Peter Pericles. 2003. Barthes dan Imperium Tanda. Yogyakarta: Jendela

Williams, Raymond. 2009. Televisi. Sleman: Resist Book 